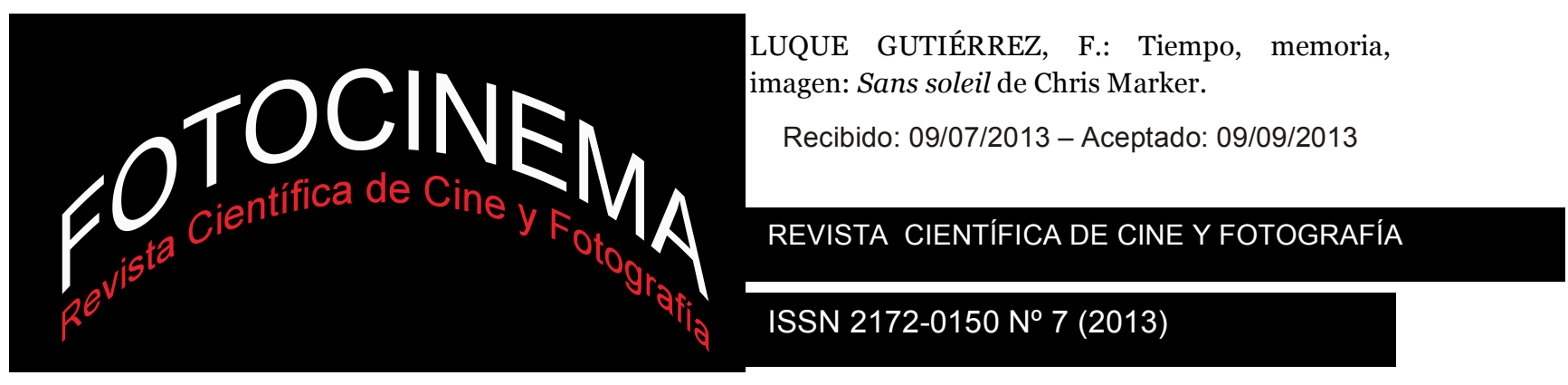

\title{
TIEMPO, MEMORIA, IMAGEN: SANS SOLEIL DE CHRIS MARKER
}

\section{TIME, MEMORY, IMAGE: CHRIS MARKER'S SUNLESS}

\author{
Fernando Luque Gutiérrez \\ Universidad de Córdoba, España
}

\section{Resumen:}

Considerado uno de los ejemplos más representativos del ensayo fílmico, el cine de Chris Marker se ha caracterizado hasta la reciente fecha de su muerte por una insistente interrogación sobre el poder y la función de la Imagen. En este sentido, el filme Sans soleil (1982) supone una referencia ineludible al establecer un punto de acceso a una nueva etapa de su dilatada carrera donde el interés por las imágenes del presente se iría sustituyendo por una obsesión por las imágenes del pasado, ya sean aquellas que han servido para escribir la Historia, ya sean aquellas de carácter más íntimo que se arremolinan caóticamente en las memorias individuales. Unas y otras imágenes componen Sans soleil, imágenes acumuladas por un coleccionista consciente de la especial melancolía que las impregna, y que pasan a constituirse en escritura fílmica. Es precisamente esta escritura el objeto de estudio del presente artículo, más concretamente, la manera en la que ésta desarrolla un característico discurso sobre el tiempo, la imagen y la memoria que se demostrará decisivo en la posterior filmografía markeriana.

\begin{abstract}
:
Chris Marker's films, which are considered to be some of the most representative examples of film-essay, have been marked until his recent death by a persistent questioning over the power and the purpose of Image. His film Sunless (1982) is at that respect an unavoidable reference when establishing a first step into a new phase within his long career. A phase where he slowly dropped interest for images of the present and developed instead an obsession for images from the past. The obsession comprised those images used to write History, as well as the more intimate ones that belong to the chaotic flow of individual memories. Sunless is made out of both kinds of images. Images accumulated by a collector who is aware of the special melancholy they are steeped in. Images that become film writing themselves. This article explores this writing, and more specifically, its characteristic discourse about time, image and memory, which will prove to be decisive along the following markerian filmography.
\end{abstract}

Palabras clave: Ensayo fílmico; Documental; Chris Marker; Cine; Fotografía; Imagen digital.

Keywords: Film-essay; Documentary; Chris Marker; Cinema; Photography; Digital image. 
o.

Sobre fondo negro, irrumpe una voz femenina: La primera imagen de la que me habló fue la de tres niños en un camino en Islandia, en 1965¹. Como respuesta, y mediante corte neto, se ofrece la imagen en cuestión: una niña acompañada de dos niños menores avanzan cogidos de las manos sin apartar la vista de la cámara que como un extraño voyeur les observa (F1). La narradora calla momentáneamente. Silencio absoluto. Sólo imagen. Y por fin, el negro acompañado por la voz de la mujer: Me dijo que para él era la imagen de la felicidad, (...) también que había tratado varias veces de unirla a otras imágenes pero que nunca funcionaba. El montaje yuxtapone entonces una nueva imagen: un avión de combate estadounidense (F2). Sin lugar a la continuidad, sin atisbo de sutura entre una imagen y otra. Efectivamente, no funciona. La narradora sentencia: Él me escribió: un día tendré que ponerla sola al comienzo de una película entre dos imágenes totalmente negras; así, si no ven la felicidad de la imagen al menos verán el negro.
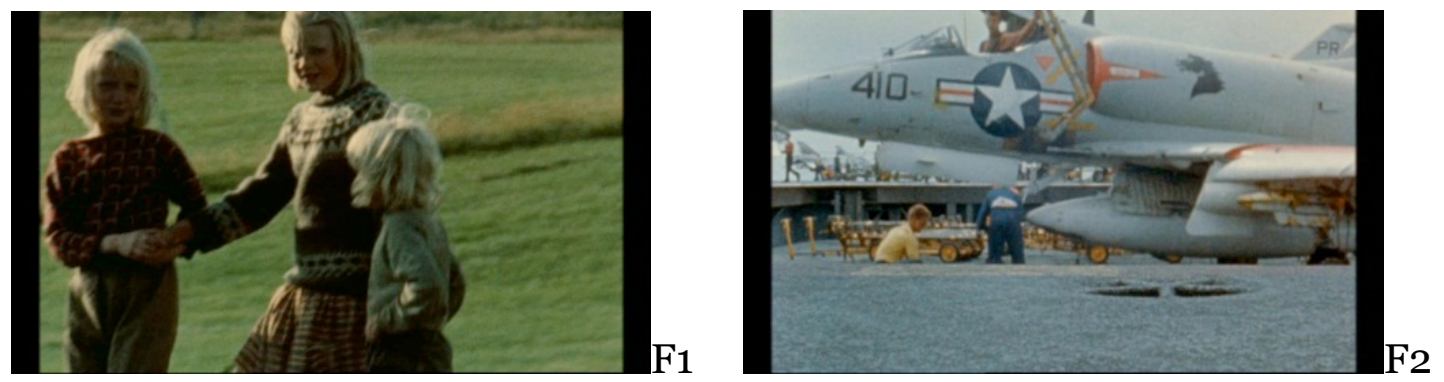

Esa película es Sans Soleil (Sin sol, 1982). Un texto clave por cuanto tiene de compendio, de síntesis de aquellos rasgos formales y temáticos que han definido la obra del viajero y cineasta francés, conocido como Chris Marker.

\section{Introducción}

Si simplificamos el filme hasta quedarnos en la más básica de sus capas, podemos definir Sans Soleil como una composición ensayística construida a partir de las imágenes recolectadas alrededor del mundo por el misterioso viajero y camarógrafo Sandor Krasna, y de las reflexiones que éste transmite

${ }^{1}$ La traducción de los textos extraídos del comentario verbal del filme está tomada de la edición en DVD de Sans Soleil editada por Intermedio (Prodimag, 2011).

210 
en una serie de cartas leídas en off por una desconocida mujer. Sin embargo, como es habitual en el cine de Marker, se trata tan sólo de disfraces, identidades prestadas (Kohn, 2006, 107-108) que permiten al autor enmascararse tras figuras enunciativas confusas, esquivas, y acentuar la sinuosa construcción del “yo” en sus ensayos fílmicos. Así, el directo os escribo desde un lugar lejano empleado en la fundamental Lettre de Sibérie (1958) se sustituye aquí por el también evocador pero mucho más distanciado él escribió... como la principal fórmula utilizada para introducir esa serie de reflexiones que, en combinación con el montaje de las imágenes, pondrán en juego motivos tan variopintos como niños islandeses y aviones norteamericanos; manifestaciones políticas y ritos funerarios por animales desaparecidos; mujeres en los mercados de Cabo Verde y emús en la Île de France... la lista es extensa.

Marker es un flaneur (...) que ha recolectado un vasto inventario de imágenes y que desde muy pronto se planteó cómo organizarlas: cómo pasar de la colección a la escritura, según la feliz expresión de Guy Gauthier, quién también recuerda que Marker ya se planteaba este problema en 1960, al comienzo de la narración de Description d'un combat: comunicar... establecer un orden, una relación entre cosas hostiles o incomprensibles (Weinrichter, 2006, 177).

Es precisamente esa escritura resultante la que ocupa el interés de nuestra investigación, o dicho de otro modo, la manera por la que, a través de esa relación entre cosas hostiles aludida, se articulan discursivamente cuestiones tan capitales en el cine de Marker como son: la imagen y la representación, la memoria y la revisión histórica, el arte, la política, la filosofía, la religión, las grandes derrotas y las pequeñas victorias humanas, más un (muy) largo etcétera. Todas estas cuestiones comparecen de una forma u otra en Sans Soleil, convirtiendo el filme en una referencia esencial para profundizar en el entramado conceptual desarrollado por el cineasta a lo largo de toda su trayectoria, desde sus inicios hasta esa última etapa, cada vez más alejada de las salas de cine tradicionales, en la que Marker encontraría en el video, la televisión y los nuevos medios informáticos un vehículo idóneo para proseguir la natural evolución de su lenguaje artístico.

211 


\section{Marco de estudio, hipótesis y metodología}

Por consiguiente, tomando en consideración la magnitud y complejidad tanto a nivel temático como formal de Sans Soleil, el presente artículo centra el objeto de su estudio en una concreta trayectoria, entre las muchas que operan en el entramado textual del filme, que creemos especialmente relevante, puesto que, trascendiendo los límites de la obra, será la trayectoria que oriente los futuros trabajos de ese último Chris Marker, interesado por las nuevas imágenes digitales, producto de sintetizadores y computadoras, que a principios de los años ochenta ya profetizaban el ocaso del cine analógico tradicional. Nos referimos a una línea de sentido clave, consagrada a una honda reflexión sobre el tiempo, la memoria y la imagen que, siempre con la angustia de la muerte de fondo, cruza Sans Soleil del mismo modo que cruzará Le tombeau d'Alexandre (1993), Level Five (1996), Le souvenir d'un avenir (Recuerdos del porvenir, 2001), Chats perchés (2004), o incluso ese imprescindible testamento en formato CD-ROM llamado Immemory (1998), consagrándose como una de sus principales líneas de trabajo hasta la reciente fecha de su fallecimiento.

Así, nuestro trabajo parte esencialmente de dos hipótesis que orientan su planteamiento:

1. Como advertíamos en la introducción al filme, Sans Soleil es un hito crucial en la filmografía markeriana, y lo es no sólo por sus valores cinematográficos propios, sino también por ejercer cierta función de nexo, de conector, entre el primer y el último Marker, entre las películas de viajes de sus inicios, las del periodo sesentayochista y aquellos trabajos postcinematográficos en los que la imagen analógica es sustituida por la imagen digital.

2. Ese proceso de sustitución de una imagen por otra anunciado en Sans Soleil, y que cristalizará definitivamente en Immemory, se fundamenta en una profunda reflexión teórica sobre la propia ontología de las imágenes cinema-foto-gráficas. Una reflexión teórica que, si bien ya se manifestaba en términos similares a través de buena parte de su producción anterior, 
encuentra aquí un punto de inflexión en su desarrollo cuando, en el citado prólogo, aquel que ha sido considerado un maestro del montaje, del arte del rapprochement, de acercar lo que está separado o distante (Weinrichter, 2006, 178), confiesa amargamente su incapacidad de unir una imagen concreta, que él identifica con la Felicidad, con cualquier otra.

Sustentando nuestra metodología de trabajo en el análisis textual, abordaremos una serie de fragmentos que creemos especialmente relevantes de Sans Soleil, con el objetivo de trazar a lo largo de las páginas que siguen un itinerario que ayude a arrojar luz sobre ese misterio, íntimamente relacionado con la extraordinaria naturaleza de la imagen-huella, que es planteado desde el mismo arranque del filme. Por ello, creemos necesario comenzar nuestra disertación abordando el sustrato teórico sobre el acto fotográfico que sustenta Sans Soleil de manera significativa. Entonces, como afirma el comentario, aunque nunca veamos la Felicidad en esa imagen originaria, empezaremos a vislumbrar el siniestro reverso que se oculta tras su superficie.

\section{La 1/24 parte de un segundo}

La relación personal y profesional de Chris Marker con la fotografía siempre fue constante. Estaba ya presente en sus orígenes pre-cinematográficos, en la colección de libros de viajes Petite Planète de la editorial Seuil, y desde entonces en su obra se pueden encontrar tanto libros de fotografías: Coréennes (1959) y Le Dépays (1982); como filmes construidos en base al montaje de imágenes fijas: La Jetée (1962), Si j’avais quatre dromadaires (1964) y Le souvenir d'un avenir (Recuerdos del porvenir, 2001); o, en fechas más recientes, incluso exposiciones fotográficas en el ámbito museístico: Staring Back (2007) o Passengers (2011). Pero además de por un sistemático uso de fotografías como material constructivo y expresivo, su cine destaca sobre todo por un permanente cuestionamiento teórico del hecho fotográfico, siendo precisamente Sans Soleil, tal y como advierte Margarita Ledo Andión (2005) en su libro Cine de fotógrafos, el filme que mejor permite la necesaria aproximación a estos elementos en su obra. 
Tras los mínimos títulos de inicio que siguen al prólogo dedicado a la imagen de los niños islandeses, se inserta un fragmento introductorio donde se lleva a cabo un primer recorrido por los espacios y temáticas que se demostrarán recurrentes en el filme. Considerando su condición fundacional, es especialmente significativo que justo cuando el comentario hace hincapié en la problemática relación que el ser humano entabla con el tiempo y la memoria, con el recuerdo y el olvido, se active un procedimiento que, como respuesta defensiva, convoca de manera directa a la Fotografía. Tres imágenes concretas -una mujer africana cruzando el mar en una embarcación precaria $\left(\mathrm{F}_{3}\right)$, un anciano en un humilde bar del barrio tokiota de Namidabashi (F4), una anciana y una niña en el malecón de Fogo en Cabo Verde (F5) - quedan, de súbito, congeladas. Una pausa en la que, mientras el tiempo fílmico sigue avanzando, el tiempo de cada una de estas imágenes se detiene para revelar así su origen fotográfico: fotogramas, que cobrarán vida durante la proyección gracias a un fallo de nuestro sistema perceptivo.
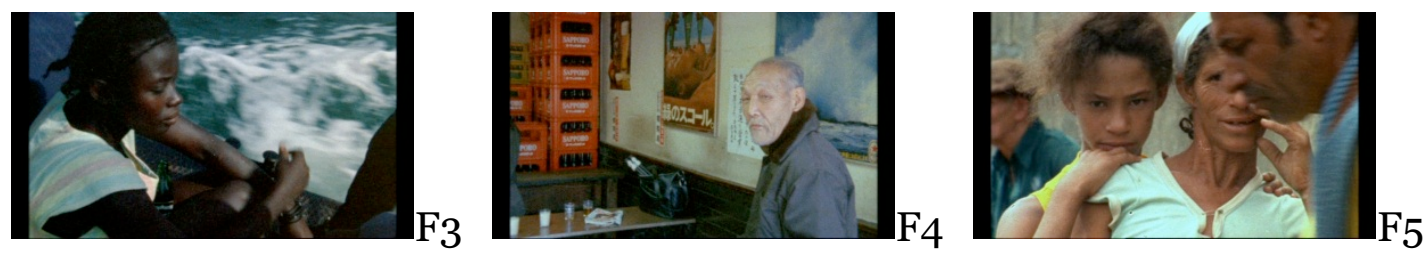

Cada una de estas tres imágenes, seleccionadas de entre las muchas que componen el fragmento, da cuenta simplemente de los rostros y miradas de unos seres anónimos que, como aquellos tres niños de la primera imagen del filme, se cruzaron con el objetivo de la cámara. Como aquella, estas imágenes simplemente retienen un momento fugaz que bien podría pasar inadvertido en la aplastante realidad cotidiana, pero que sin embargo ha sido capturado del devenir del tiempo por un artefacto mecánico. En Si j’avais quatre dromadaires (Marker, 1966) se plantea la metáfora que nos ayudará a perfilar el razonamiento: La foto es la caza, el instinto de la caza sin el deseo de matar. Es la caza de los ángeles... Ojeas, apuntas, disparas y clac, en lugar de un muerto tienes un eterno. Pero, en Sans Soleil, habrá que esperar para que esta idea que encontramos de manera embrionaria en el arranque del filme termine cristalizando definitivamente. 
Nos referimos al célebre fragmento del Mercado de Praia en Cabo Verde, donde Krasna se afana por conseguir una mirada de huidizas mujeres que se esconden del ojo mecánico de la cámara cinematográfica. La filmación de la realidad cotidiana de ese mercado africano se convierte en una persecución que culminará cuando el cámara-cazador logre abatir finalmente a su presa (F6): La veo a ella. Ella me ha visto. Ella sabe que yo la estoy viendo. Y deja caer su mirada hasta un ángulo en el que aún es posible actuar como si no fuera dirigida a mí. Y al final, la mirada real... de frente (tout droit) que ha durado la 1/24 parte de un segundo, lo mismo que el fotograma de una película.

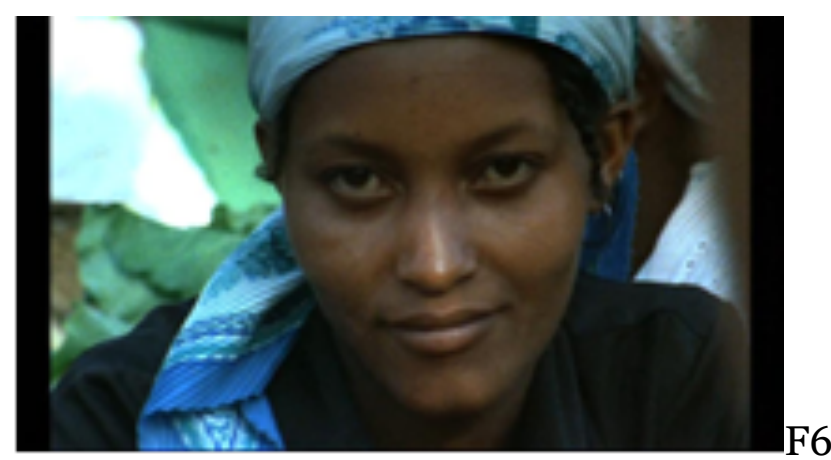

La propia configuración del fragmento nos advierte que ésta no es una imagen cualquiera dentro del intrincado collage de Sans Soleil. Ahora no se trata de la ambigua interpretación de lo escrito por un tercero, quien así se mantiene a una distancia prudencial. Como contrapunto a la tendencia dominante en el filme, la lectora trasmite en esta ocasión los escritos del viajero utilizando la primera persona: yo la veo, ella me ha visto. Aun a través de la voz femenina, el escurridizo Marker se pone al descubierto para describir de manera especialmente minuciosa todo el arduo proceso que le lleva a conseguir su objetivo, el ritual de seducción que activa la mujer y que precede al estallido de toda la fuerza e intensidad de la mirada real capturada para siempre en una imagen que, tal y como se asegura de hacernos saber el comentario que cierra la estructura, ha durado la 1/24 parte de un segundo. $\mathrm{Su}$ preciado trofeo es, según se afirma, un fotograma, o dicho de otra manera, el elemento cinematográfico más próximo a la fotografía. Un instante, inmortalizado, eterno, suspendido en un tiempo indeterminado. 
Parece confirmarse lo que en el primer tramo de Sans Soleil tan sólo era sugerido, y la recurrente reflexión sobre el tiempo y la memoria confluye de nuevo en una exaltación de la imagen-huella como testigo de ese tiempo, depositaria de esa memoria:

La fotografía (...) requiere para su consecución una relación de causalidad física con el objeto. El objeto se representa a sí mismo, mediante la luz que refleja. La imagen no es más que el rastro del impacto de esa luz sobre la superficie fotosensible: un rastro almacenado, un rastro-memoria (Fontcuberta, 1997, 78).

Podemos leer, por tanto, una señal de advertencia en cada una de aquellas imágenes congeladas en el arranque, un gesto enunciativo que ya en la presentación de Sans Soleil expresa lo extraordinario de cada una de sus imágenes, en cuanto a herramientas privilegiadas para conservar la memoria de todo lo arrastrado por el tiempo, algo que también será subrayado más adelante por el discurso verbal: Recuerdo aquel mes de enero en Tokio, o más bien recuerdo las imágenes que filmé del mes de enero en Tokio. Se han sustituido a sí mismas en mi memoria. Ellas son mi memoria. (...) me pregunto cómo recuerda las cosas la gente que no filma, que no hace fotografías, que no graba en video. Tal es la naturaleza de las imágenestesoro acumuladas por el viajero Chris Marker. Fragmentos de vida embalsamada. Huellas. Rastros. Recuerdos. Con ellos se construye el bello y doloroso homenaje al ser humano que es Sans Soleil.

\section{Historias, derrotas, imágenes}

El cine de Chris Marker, cuya obra comienza a fraguarse con Auschwitz e Hiroshima demasiado frescos en la memoria, siempre demostró una notable sensibilidad ante los acontecimientos históricos que le tocó vivir. A medida que su trayectoria avanzaba, la reflexión sobre el presente histórico (sin perder de vista el pasado), que caracterizaría tanto las películas de viajes de la primera etapa como las de su fértil periodo militante, se convertiría progresivamente en una permanente interrogación de las imágenes del pasado (sin perder de vista el presente), consagrándose definitivamente ese 
Chris Marker obsesionado por la problemática entre la historia y la memoria que a finales de la década de los setenta construiría el monumental collage de Le fond del'air est rouge (1977). Un filme fruto del montaje de todo un compendio de imágenes emblemáticas del convulso periodo de revoluciones que sacudió el planeta durante los años sesenta y setenta, del que Marker fue parte y particular cronista, e ideado como un espacio para la reflexión, para el recuento de los logros de estas luchas sesentayochistas, y, sobre todo, de sus fracasos.

Unos años más tarde, Sans Soleil vuelve a activar este mismo sentimiento agridulce de derrota, tanto personal como de toda una generación, cuando el continuo vaivén de Sandor Krasna alrededor del mundo trae consigo el recuerdo de la revolución que lideró Amílcar Cabral por la liberación y unificación de las colonias portuguesas de Guinea-Bissau y Cabo Verde. Un lugar insignificante en el mundo cuya lucha fue enarbolada por la izquierda como un triunfo, pero que acabaría siendo abandonado a su suerte una vez se retiraron los focos de la prensa y la opinión pública internacional. Melancolía y decepción tiñen las imágenes del presente guineano de los años 80 filmado por Krasna en el muelle de Pidjiguity, el lugar físico donde todo empezó en 1959 con las primeras víctimas. Es allí donde Marker se posiciona para volver a manifestar una de las constantes más nítidas de su cine, la férrea voluntad de revisar los acontecimientos del pasado practicando una historiografía que, como bien apuntan Ortega y Weinrichter (2006, 33), suele traducirse en el exhaustivo análisis de aquellas imágenes con las que se ha escrito (o no) la Historia ${ }^{2}$.

Revisando el proceso revolucionario en África, Marker complementa una antigua filmación de Amílcar Cabral, despidiéndose de los suyos en las islas

\footnotetext{
${ }^{2}$ En su primera video-instalación museística Quand le siècle a pris forme, guerre et révolution (1978), trabajó a partir de found footage relativo al primer tercio del siglo XX haciendo especial hincapié en imágenes de la I Guerra Mundial y la imaginería revolucionaria soviética; y en 2004, realizó Le souvenir d'un avenir, un film en el que intenta descifrar en las imágenes que la fotógrafa Denise Bellon realizó durante el periodo de entreguerras, el anuncio del trágico futuro que esperaba a la vuelta de la esquina con la II Guerra Mundial y las insurrecciones coloniales de posguerra. Entre una obra y otra, los ejemplos de este interés han seguido siendo frecuentes en sus trabajos, siendo la Unión Soviética de Medvedkin en Le Tombeau de Alexandre (1993); o la barbarie de Okinawa en Level Five (1996) los trabajos más destacados.
} 
Bijagós antes de iniciar la lucha que traería consigo la independencia de Cabo Verde y Guinea-Bissau, con otra imagen en la que, quince años después, su hermano, Luiz Cabral, exactamente con el mismo gesto y en la misma localización, saluda a su regreso tras ser investido presidente de la nueva nación. La ilusión por lo que estaba por venir frente a la momentánea satisfacción tras la victoria. Inicio y fin de la revolución. Entre lo uno y lo otro: imágenes frenéticas tomadas cámara en mano siguiendo a guerrilleros por la jungla; jóvenes precariamente uniformados posando ante el objetivo; los abrazos de los combatientes con los visitantes europeos que filmaban y defendían su causa.

Estas últimas imágenes que, como informan los créditos finales, se toman prestadas de las filmaciones que Mario Marret 3 y Eugenio Bentivoglio realizaron de la guerrilla en Bissau, desembocarán a su vez en otras filmadas por Jean-Michel Humeau en 1980 que dan testimonio de la conmemoración del séptimo aniversario de la victoria, y donde han quedado registrados los efusivos gestos de cariño entre los políticos del nuevo país y los militares honrados por su labor en aquellos años de cruentas luchas. Marker incorpora en su discurso estas filmaciones ajenas, cuya organización cronológica resumiría ese episodio histórico a la manera de un relato convencional: con un inicio, un nudo y un necesario desenlace. Sin embargo, sólo habría que esperar el paso del tiempo para comprobar que esa imagen final que parecía la de la confirmación de la victoria en realidad sólo era un nuevo comienzo, marcado por el golpe de estado que encabezarían precisamente los mismos militares que entonces eran condecorados.

Con Amílcar asesinado, las facciones guineanas y caboverdianas que lucharon juntas acabarían enfrentándose por su legado. Los héroes de una causa común que levantó la admiración de Occidente se matarían entre sí, volviéndose villanos antes de que la admiración se volviera indiferencia, y lo que en teoría debiera ser una tierra liberada en la práctica se convirtió en un territorio regido por pequeños tiranos sanguinarios. De la filmación de Humeau, Marker destaca el cariñoso abrazo entre Luiz Cabral y el

3 Compañero de Marker en la realización de À bientôt j'espère (1968). 
comandante Joao Bernardo "Nino" Vieira. Un año después, Cabral estaría preso y Nino, quien lloraba al recibir la medalla, ocuparía su puesto en el poder hasta que fuera derrocado, exiliado y finalmente asesinado por sus oponentes políticos en 2009. Ahí está la imagen registrada: las lágrimas, la mirada perdida, los ojos posados en el suelo, y sin embargo necesitaríamos esperar para aprender el verdadero sentido de los signos en ella inscritos: Aprenderemos que tras esa fiesta de entrega de grados (...) se escondía todo el resentimiento del día después de la victoria, y que las lágrimas de Nino no representaban la emoción del viejo guerrillero, sino el herido orgullo del héroe al que no se considera más distinguido que al resto. Estos pequeños países africanos atestiguan así el inquebrantable bucle que parecería afectar a cada uno de los procesos revolucionarios acontecidos a lo largo del siglo pasado, sólo cambiarían las coordenadas y los protagonistas. Las manos frágiles se convierten finalmente en manos cortadas, incapaces, a medida que son aplastados los sueños de la revolución. Pero queda la memoria grabada en la imagen, y con ella la posibilidad del aprendizaje.

El tiempo se repite, es cíclico. Pero la repetición de la historia otorga saber, nos hace más sabios. ¿En qué consiste esa sabiduría? Sans Soleil, es la primera película de Marker verdaderamente reflexiva sobre esos temas, tras su periplo por la debacle de las revoluciones de los sesenta y los setenta (Losilla, 2006, 141).

En la opuesta Japón, tras encontrarse con los fabulosos avances tecnológicos de la ingeniería robótica y su anuncio de un futuro propio de la cienciaficción, Krasna se interna en las calles del barrio tokiota de Yurakucho, donde, erigido como un monumento conmemorativo más de la ciudad, el Sr. Akao, antiguo líder de la derecha ultranacionalista, lanza diatribas a través de los altavoces instalados en su furgoneta. Con su figura, la promesa de futuro se convierte de súbito en el recuerdo de un pasado que se pensaba superado cuando una filmación de archivo en blanco y negro nos presenta al Sr. Akao, diez años menos viejo, denunciando sobre la misma furgoneta un supuesto complot comunista oculto en las movilizaciones contra la construcción del aeropuerto de Narita, una revuelta iniciada por los campesinos desplazados 
tras la expropiación de sus tierras y secundada por estudiantes y los sectores más radicales de la izquierda. El blanco y negro vuelve a convertirse en color, el pasado en presente, y, sin embargo, como demuestra la confrontación de las imágenes de lo viejo y las imágenes de lo nuevo, nada parece haber cambiado. La cámara se sumerge en una movilización en homenaje a las víctimas, llena de adolescentes, de panfletos, de símbolos $\mathrm{y}$, como no, de policías antidisturbios. Marker afirma que el regreso a Narita le ha reenviado a un fragmento intacto de la Historia para reencontrarse de frente con la imagen perdida de la generación de los sesenta. Una sensación alucinatoria de déjà vu, en la que sólo destaca una simple pero decisiva modificación, ácidamente subrayada: el aeropuerto, ya construido, cerrando la composición como símbolo de la derrota.

Los campesinos no lograron conservar sus tierras, los estudiantes más radicales se enfrentaron entre sí por ser los garantes de la pureza revolucionaria y otros con el tiempo se convertirían en los mejores ejecutivos de las grandes empresas capitalistas que antes trataban de combatir, pero, sobre todo, el aeropuerto finalmente no sólo se edificó sino que fue expandiéndose hasta convertirse en uno de los de mayor tráfico de todo Japón. Como decíamos, en el fondo de todo está la escritura y el sentido de la Historia, y más concretamente, el papel que juegan las imágenes en ello. Más allá del conocimiento obtenido gracias a la lucha, lo que parece enseñarnos la confrontación de las imágenes del pasado y del presente es la repetición de un ciclo, como el de las olas que furiosamente chocan contra las rocas del acantilado. Así es como avanza la Historia -dice Krasna- tan previsible que hay que creer en una especie de amnesia del futuro que la Historia distribuye, por misericordia o intencionadamente, a aquellos que recluta.

Podemos evidenciarlo en el mercado de Praia de Cabo Verde, donde ese olvido misericordioso permite a los seres humanos dejar atrás el sufrimiento para seguir luchando por su supervivencia, aun a costa de quedar condenados a repetir los mismos errores. Podemos, incluso, olvidarnos de que la Historia no entiende ni atiende a nada ni a nadie, y de que su único aliado es el horror, tal y como recuerda Marker que aseguraba el coronel 
Kurtz en Apocalypse Now (Francis Ford Coppola, 1979). Sin embargo, ya lo advertíamos, quedan las imágenes. En ellas ha quedado fijada la huella de los niños armados, de los cuerpos agonizantes, de la carne podrida. Y ellas atestiguan con crudeza que, efectivamente, el horror tiene un nombre, y un rostro $(\mathrm{F} 7)$.

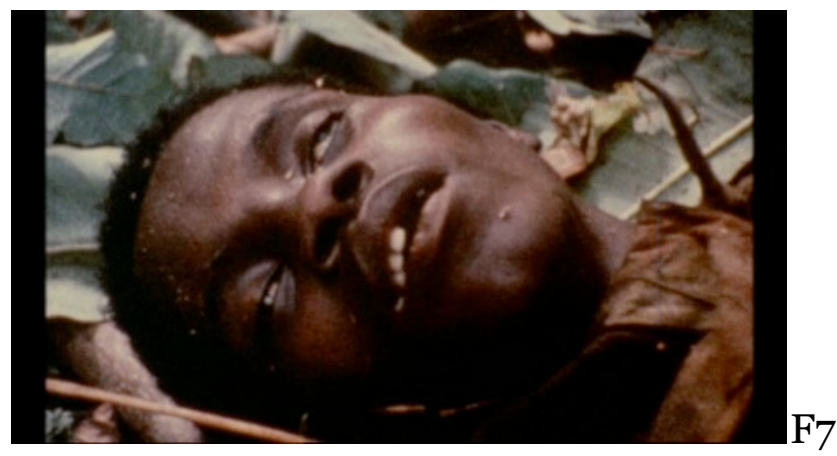

Comentario e imagen confluyen finalmente sobre la desoladora visión de un joven guerrillero devorado -literalmente- por los gusanos. Ella es precisamente la encargada de cerrar el bloque que Sans Soleil dedica al proceso revolucionario en África. Si como sostiene Guy Gauthier, estudioso infatigable de Marker, en su cine, la fotografía de los rostros es objeto de la memoria, es el testimonio de una relación humana que desafía al tiempo y al espacio (2003, sp), cabría preguntarse por cómo se ve afectada esa relación humana establecida a partir de la mirada del otro fotografiado cuando su rostro es la mismísima máscara del horror, físico y matérico, que se erige en el más radical signo de la derrota.

\section{Re-escribir la memoria}

Podemos, por tanto, perfilar de manera algo más nítida la problemática relación entre memoria e imagen puesta en juego en Sans Soleil. Contrarrestando esa suerte de amnesia aludida por Krasna en relación a los funestos acontecimientos en las revoluciones de los sesenta y setenta, esa misma imagen-huella reivindicada como la necesaria garante de la memoria del pasado, fuente de conocimiento y sabiduría, termina inevitablemente por revelarse como un cruel testimonio del horror de la Historia que nuestra mente trata de enterrar en el olvido como mecanismo de defensa, 
demostrándose así capaz de proyectar de manera dolorosa el pasado sobre el presente. En este sentido, consideramos que Sans Soleil desarrolla una vieja idea que venía ya siendo trabajada por Marker desde sus inicios como cineasta, y así se demuestra en obras como Nuit et brouillard (Noche y niebla, 1955), donde colaboró como ayudante de dirección con su amigo, y miembro destacado en la llamada orilla izquierda del nuevo cine francés, Alain Resnais.

Realizada a partir de las terribles imágenes que documentaron los campos nazis de exterminio, Nuit et brouillard quizás sea la obra más impactante, por su crudeza, de todas las realizadas por el tándem Marker-Resnais durante la década de los 50. Pero lo que nos interesa remarcar serán las similitudes que desde entonces encontraremos en los trabajos donde, ya por separado, estos dos cineastas herederos del pos-apocalíptico mundo dejado por la II Guerra Mundial seguirían tratando el conflicto antagónico al que se ve sometida la memoria humana: el dilema entre conservar el poso de saber obtenido con la tragedia, para evitar que vuelva repetirse, o bien tratar de olvidarlo todo para alejar el dolor que conlleva su recuerdo.

Concretamente, desde el movedizo terreno de la no-ficción Sans Soleil moviliza las grandes preocupaciones que ya sustentaran dos de las ficciones más célebres de Resnais -Hiroshima, mon amour (A. Resnais, 1959) y La année dernière à Marienbad (1961)-, conjugando la difícil convivencia con el recuerdo del holocausto atómico de la primera, con la memoria obsesiva y confusa que condena a los personajes de la segunda a vagar por los claustrofóbicos pasillos y espacios de una mansión fantasmagórica presos de la ensoñación de lo que fue, o pudo ser, o jamás fue. He aquí la cuestión, el punto neurálgico al que nos lleva la reflexión sobre los traumas de la memoria planteada por Marker: donde nos quieren hacer creer que se ha forjado una memoria colectiva hay millones de memorias humanas que pasean su herida personal dentro de la gran herida de la Historia. Mientras que la Historia oficial, la de los eventuales vencedores, es re-escrita, a 
conveniencia, en un relato historiográfico, artificial y propagandístico ${ }^{4}$, que intenta racionalizar la crueldad y el sinsentido de la espiral del tiempo Hiroshima, Auschwitz, Cabo Verde... sólo por ejemplo-, en cada uno de nosotros se va edificando una memoria propia, compuesta de incontables fragmentos desordenados que configuran un universo, abstracto y caótico, donde nos vemos arrastrados al continuo enfrentamiento con las heridas del pasado en nuestro particular Marienbad.

Aquí entra en escena un filme fetiche: La locura protege, como la fiebre (...) él me escribió que sólo un film habla de la memoria imposible, de la memoria loca, una película de Hitchcock: Vértigo. Para Marker, a través del personaje protagonista se plantea una cuestión fundamental: la imposibilidad de convivir con la memoria si no es falseándola. Scottie (James Stewart) se revela finalmente como un hombre traumatizado por la muerte de su amada, que trata de materializar un fantasma, una doble, una nueva Madeleine, inventada en otra dimensión del Tiempo: Parece ser una cuestión de vigilancia, de enigma, de asesinato, pero en verdad es una cuestión de poder y de libertad, de melancolía y de vértigo, tan cuidadosamente codificados en el interior de la espiral que nos podemos equivocar...y no descubrir que ese vértigo del espacio es en realidad el vértigo del tiempo. Incidiendo en esta lectura del filme de Hitchcock, entre los textos incluidos en la interfaz del CD-ROM Immemory (1998) podemos leer estas explícitas palabras:

Vértigo es la historia de un hombre que ya no soporta esta dictadura de la memoria: lo que ha ocurrido, ha ocurrido y nadie puede cambiar ya nada. Él quiere cambiar. Quiere que (...) una muerta vuelva a la vida, quiere sencillamente vencer al tiempo. (...) Ninguna película había mostrado jamás hasta tal punto que si desajustamos el mecanismo de la memoria, puede servir para algo totalmente distinto del recuerdo. Para reinventar la vida y, en última instancia, para vencer la muerte.

4 Este aspecto ocuparía un lugar central en obras posteriores como Le tombeau d'Alexandre (1993), en relación al uso propagandístico de la imagen durante la Unión Soviética, y en Level Five (1996), en lo referente a la II Guerra Mundial y la batalla de Okinawa.

223 
Tras analizar las similitudes entre Vértigo y La jetée (Marker, 1962), Carlos Losilla ya apunta que en ambos casos el intento de modificar el pasado de sus protagonistas sólo deparará devastadoras consecuencias (2006, 140). Sin embargo, Sans Soleil no pretende valorar la viabilidad de esta estrategia de autodefensa. Lo que subraya es la necesidad propia del ser humano de albergar, por irracional que esta sea, una mínima esperanza que lleve a creer que se puede vencer a esa dictadura de la memoria referida por Marker en Immemory, re-escribirla, igual que rescribimos la Historia, para vencer al tiempo, en definitiva, a la muerte, y, aún más, si tal esperanza estaría relacionada de alguna manera con las imágenes de origen cinema-fotográfico.

\section{Lo que nos grita desde la imagen}

Advertíamos anteriormente que, latiendo bajo la reflexión sobre el tiempo, la memoria y la imagen, en Sans Soleil encontramos agazapada la amenazante certeza de la muerte esperando el momento oportuno para emerger a la superficie. En 1980, Roland Barthes afirmaba en La cámara lúcida que la fotografía es la manera por la que nuestra época asume la muerte. En la coetánea Sans Soleil, Marker también subraya la relación entre muerte e imagen cinema-foto-gráfica cuando las imágenes congeladas en el primer tramo del filme desembocan de manera certera en la filmación de un conjunto de animales descomponiéndose, casi fosilizados, en el desierto africano del Sahel.

Esa obsesión por la representación de la imagen congelada (...) que conduce a la idea de la muerte, de la memoria a la vez moribunda y aniquiladora, es propia de una época en la que el cine ha perdido su inocencia, y empieza a contemplarse a sí mismo como un mausoleo, como un cementerio hecho de imágenes fantasmagóricas que pasan a pertenecer al pasado en el momento mismo en que se filman (Losilla, 2006, 141).

Como advierte aquí Carlos Losilla, ese interés por la imagen congelada y su vinculación con la muerte, patente en Sans Soleil, entronca con todo un 
sustrato teórico que en los albores de la era digital ponía el acento en la naturaleza fantasmagórica de la imagen-huella analógica, la cual, indica Ángel Quintana, siempre se encuentra impregnada de un "sentimiento de duelo, de resurrección de lo ausente" $(2011,52)$. Tomemos como ejemplo la imagen-recuerdo fundacional de los tres niños islandeses, la cual remite a una fracción de tiempo específica e irrepetible de un día del verano de 1965, un presente que fue sepultado por el Tiempo convirtiéndolo en un recuerdo arremolinado en la memoria pero que, sin embargo, permanecerá por siempre vivo en la imagen conservada, permitiendo ese sentimiento de resurrección de lo ausente, expresado por Quintana y ejemplificado por Barthes, también en La cámara lúcida, en la célebre reflexión surgida del poderoso impacto que le causó su fortuito encuentro con una antigua foto de su madre:

La fotografía del Invernadero, por descolorida que esté, es para mí el tesoro de los rayos que emanaban de mi madre siendo niña, de sus cabellos, de su piel, de su vestido, de su mirada, aquel día (Barthes, 1990, 144).

Es la condición de huella de la imagen fotográfica la que despierta en Barthes ese inigualable sentimiento de re-conexión con su madre ya fallecida, la que permite conservar el tesoro que supone el rastro lumínico de su cuerpo real en el pasado, en aquel instante engullido por el paso del tiempo, y que ahora le es devuelto igual que "los rayos diferidos de una estrella" (1990, 142). Y así, en Sans Soleil las imágenes de la muerte en el Sahel (F8) son engarzadas con otras, filmadas en el carnaval de Bissau, donde las máscaras anuncian la resurrección simbólica de los animales con la llegada de la primavera (F9).
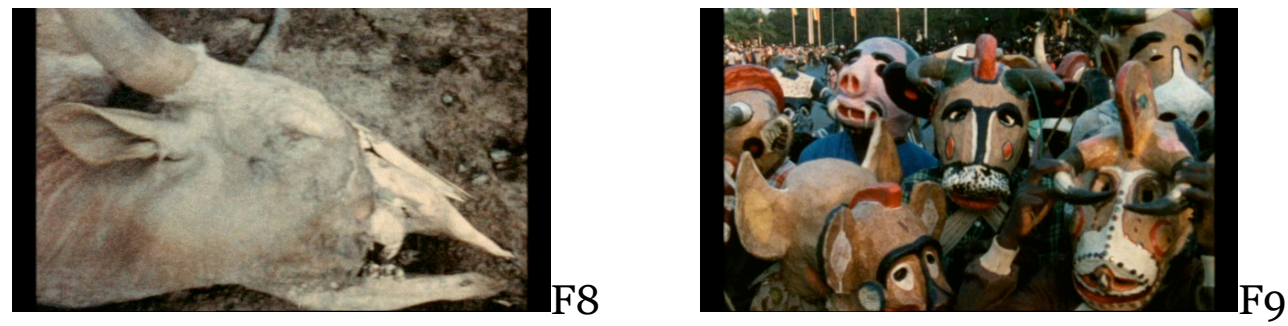

No en vano, el filme markeriano empareja a Japón y África, como representantes de los dos polos extremos de la supervivencia, en base a una 
similar manera de entender la muerte que se opone a la de nuestra cultura europea, es decir, la muerte no como tabique sino como camino a seguir. Rastreando esta sensibilidad, entre los muchos ritos de carácter funerario que comparecen en Sans Soleil, destaca la ceremonia del zoológico japonés de Ueno en memoria de dos pandas muertos. Según somos informados, los animales habían fallecido dos años atrás. La desolación sentida durante el primero de ellos había dado paso a la aceptación de que cada cierto tiempo la muerte tenía que llevarse a alguno de estos animales tal y como hacen los dragones de los cuentos con las chicas jóvenes. Justo con la evocación del cuento infantil, imagen y comentario se centran en un grupo de niños que imitan con curiosidad el comportamiento de los adultos: como si intentaran, para comprender la muerte de un animal, ver a través del tabique. Se trata por tanto del aprendizaje, del rito iniciático, de ahí la alusión explícita del comentario a los cuentos fundadores, a los relatos míticos que pueden dotar de sentido a la existencia, y muerte.

Durante un extenso fragmento que Sans Soleil dedica a analizar la televisión japonesa, dice Krasna: Para expulsar al horror con nombre y rostro, hay que darle otro nombre y otro rostro. Justo antes, la sucesión de imágenes proyectadas desde esa caja de recuerdos que es el televisor daba pie a la inesperada asociación del pensador que proclamó que el hombre es bueno por naturaleza y una de las demostraciones históricas más radicales de la violencia que ese mismo hombre ha sido capaz de manifestar: 8:40, Camboya. De Rousseau a los jemeres rojos. ¿Casualidad o sentido de la Historia? Si bien tal asociación de motivos, en principio lejanos y hostiles entre sí, traza un hilo de continuidad que subraya el agrio sentido de la Historia tratado por Marker en relación a los acontecimientos históricos de Cabo Verde, lo que verdaderamente destacamos ahora es el siguiente paso, esto es, las estrategias del ser humano para poder soportarlo, para exorcizar los demonios que le atormentan valiéndose de sus sustitutos en el simulacro de la representación. Así, si diferenciamos desde el punto de vista indicial las imágenes empleadas para introducir ambas proposiciones, comprobamos que la pura imagen documental en el caso de la tumba del ilustre filósofo se 
sustituye por la imagen pictórica para poder representar la extrema brutalidad de una realidad histórica sin la pesada carga de la huella fotográfica (F10), para poder dar, en definitiva, otro rostro al horror gracias a la expresión plástica. Hacia allí apunta el cine de terror asiático -producto de un pueblo tan acostumbrado al sufrimiento que exige que hasta el dolor sea adornado- y hacia allí se dirige la reflexión markeriana cuando cierra la estructura con una serie de fotogramas extraídos de películas de terror japonesas (F11): imágenes del reino de sombras de la ficción, las cuales, tratando de negar su propia ontología, desajustan los intrínsecos vínculos con la realidad de la que son arrancadas y son engarzadas en la construcción fílmica de un relato que, como los cuentos fundadores, calme esa misma necesidad de dar un sentido al sufrimiento y la muerte que plantea Marker con respecto al rito funerario de Ueno.
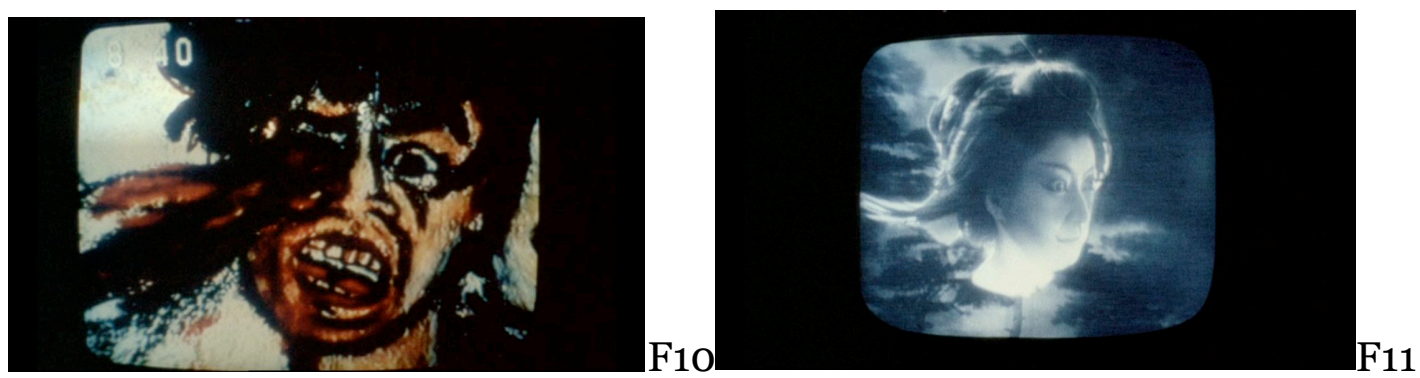

Retomando el tema de la reescritura de la memoria planteado por Marker en su análisis de Vértigo, si, como sostiene Krasna, las imágenes mecánicas usurpan el lugar de nuestros recuerdos, reemplazándolos irremediablemente, parecería posible que ellas mismas nos permitieran desajustar el mecanismo que rige nuestra memoria, y re-escribirla del mismo modo que nos permiten crear las realidades alternativas del cine de ficción. Pudiéramos pensar que es suficiente con fijar en la memoria las imágenes de aquello que creyéramos conveniente salvar del olvido, para posteriormente tratar de construir a partir de tales fragmentos un relato, propio, por el que se encauce la necesidad de "ver a través del tabique", de abrir un punto de fuga a una (otra) dimensión temporal donde poder reencontrarnos, tal y como intentara Scottie, con nuestra personal Madeleine. Al menos eso parece pensar un Marker obsesionado con rastrear entre las ruinas del siglo XX los espacios donde arden los sueños rotos de la humanidad, acumulando imágenes para 227 
la esperanza, donde aferrarse, donde conservar el recuerdo de aquello que nos hace levantarnos y participar de la lucha continua que supone la supervivencia, de esa energía atestiguada en aquella mirada femenina del mercado de Praia, pura y directa, capturada en un valioso fotograma por ese mismo cámara-cazador que conserva celosamente en la mirada de tres niños islandeses la imagen de la Felicidad, y la protege entre dos abisales pantallas en negro.

Sin embargo, el aprendizaje en Ueno será utilizado por la pedagogía markeriana para manifestarse con especial virulencia, negando en última instancia tal posibilidad. Entre la serie de planos dedicados a los niños japoneses participando en la ceremonia, se injertan bruscamente un par de elementos fuera de contexto. Primero, una jirafa corriendo por la sabana africana. Segundo, una imagen tomada de una ficción japonesa en la que un ninja efectúa un disparo dirigido hacia el fuera de campo. Dos desgarros. Dos interferencias que desorientarán al espectador hasta que la magia del montaje consiga que animal y disparo se conjuguen en un imposible planocontraplano de funestas consecuencias.

Las imágenes de la cacería de una jirafa cualquiera fueron tomadas por Danièle Tessier. Marker las re-utiliza para convertir la ceremonia funeraria, con el mito y la mirada infantil en juego, no lo olvidemos, en la contemplación desnuda de la agonía filmada del animal. Así se cierra la estructura que fuera iniciada hablando de consuelo en un zoológico japonés, y lo hace de la misma manera que se cerraba esa otra estructura, analizada anteriormente, que hablaba de esperanza y revolución en un país africano: con una imagen de la muerte. No una imagen cualquiera, sino la resultante de la mediación de una máquina cinematográfica, sin prejuicios ni moral, que como un ente vampírico succiona los últimos instantes que conducen a ese destino común de humanos y animales, y los registra para siempre en una superficie fotosensible. Decía Pascal Bonitzer que "el objeto no grita de la misma forma sobre una tela que sobre una foto (...) eso lo cambia todo" (Dubois, 1999, 45). Retomando sus palabras, qué decir cuando es la muerte la que grita. No una muerte simulada, puesta en escena, sino la muerte física, 
real, revelada en la imagen gracias a procesos físico-químicos. Frente al rito que trata de dar un sentido a la muerte, frente a la leyenda que trata de descifrar lo indescifrable y procurar un consuelo, la imagen-huella mecánica revela la crueldad que surge de lo real, más allá de cualquier código o de cualquier formalización, como última y fundamental enseñanza.

\section{Una imposible ficción: Sin sol}

Nos acercamos al final de un trayecto iniciado por Marker en la primera imagen de Sans Soleil. El comentario verbal introducirá en el último tramo del filme la idea para un proyecto cinematográfico que Krasna dice querer realizar. Se trata de una película de ciencia-ficción, con claras reminiscencias de La jetée, la cual narraría la historia de un viajero del tiempo proveniente del año 4001, un tiempo en el que el cerebro humano ha alcanzado su máximo rendimiento y todo funciona a la perfección, incluida la memoria. Sin embargo, para Marker, esa memoria total sería una memoria anestesiada: En el mundo del que viene, evocar un recuerdo, emocionarse ante un retrato, temblar al escuchar una música... no pueden ser más que signos de una prehistoria larga y dolorosa. En este contexto, el protagonista es un individuo especial, que tiembla de indignación como los jóvenes de los sesenta, ante la mera posibilidad de que haya existido la infelicidad en su planeta. Él quiere entender, y para ello inicia una particular búsqueda a través del entramado espacio-tiempo de nuestra era guiado por un ciclo de viejas melodías, que se siguen cantando en el siglo cuarenta aunque ya han perdido cualquier significado: Sin Sol, del compositor ruso Modest Mussorgsky, donde percibe por primera vez la presencia de eso que no comprende y que tiene que ver con la desgracia y la memoria. Naturalmente, avisa la narradora, fracasará. Del mismo modo, Krasna reconoce saber que este es un proyecto que nunca llegará a realizar, pero en su carta nos informa de que poco a poco va inventándose los diálogos, coleccionando sus escenarios y criaturas favoritas -lechuzas, gatos, humanos- y que, incluso, ya tiene preparado un título: el mismo que las melodías de Mussorgsky, Sans Soleil. 
Una sacudida recorre el cuerpo del espectador ante la duda de si todo lo visto hasta el momento tan sólo es el esbozo de una ficción imaginaria, tal es la complejidad de la peculiar operación de puesta en abismo que se plantea. Sin embargo, lo que queremos destacar según los objetivos del presente estudio no es tanto el hecho de que Marker, aun a través de su alter-ego, avise de su necesidad personal de construir su particular simulacro ficcional para, siguiendo con el planteamiento anteriormente señalado, expulsar el horror, sino la confesión de que nunca podrá llevarlo a cabo: En Islandia puse la primera piedra de una película imaginaria... Entonces, recordamos la insistencia de Krasna al avisar en el arranque del filme de la imposibilidad de unir la imagen de Islandia con otras imágenes. No funciona, nos decía mientras trataba de enlazarla con otra imagen-recuerdo, la del avión de combate estadounidense, que nos remitiría inevitablemente en aquel año 65 al por entonces todavía incipiente horror de la guerra en Vietnam. Y es que, como ocurriera con la película hitchcockiana, lo que subyace en el planteamiento de Sans Soleil, más allá de su complejidad, es también una cuestión de identidad, de melancolía, y, sobre todo, de un abrumador vértigo, no del espacio, sino del Tiempo.

El gesto retórico de la obertura (...) convierte la imagen de Islandia en un fetiche. Pero el mejor sitio para guardar un fetiche es una vitrina en la que los objetos depositados son visibles, pero intangibles. La imagen de Islandia parece estar alojada en una vitrina, enmarcada por franjas negras protectoras que la guarecen de interferencias con otras imágenes 5 .

Depositado como un fetiche en esa vitrina de la que habla Birgit Kämper, lejos de toda interferencia para evitar su contaminación, el registro filmado de ese instante adquiría un significado íntimo que lo identificaba, recordemos, con la imagen de la Felicidad. Posteriormente, esta fundamental imagen será retomada por Marker con motivo de una filmación que el geólogo H. Tazieff realizó en 1970 tras una erupción volcánica que

5 Kämper, B: Dokument und Erinnerung als Problem filmischer Ästhetik: Eine Untersuchung zu Chris Marker Film-Essay "Sans Soleil”. En Tode, T: Fantasma Marker..., op. cit. p. 71.

230 
sepultó bajo un manto de materia negra la pequeña localidad islandesa de Heimaey, el espacio físico donde Marker y los niños coexistieron aquel día de 1965: Sólo había que esperar y el planeta, por sí solo, pondría en escena el trabajo del Tiempo. Pero en esta ocasión Marker la reinserta sin pulir, en bruto, incluyendo aquello que antes había eliminado para hacerla más nítida: los niños se han alejado un poco del punto donde está situada la cámara y esto permite que, al abrir el campo de visión, podamos contextualizar adecuadamente el espacio donde se encuentran y ver el camino que les dirige hacia un brumoso horizonte divisado al fondo de la composición (F12).

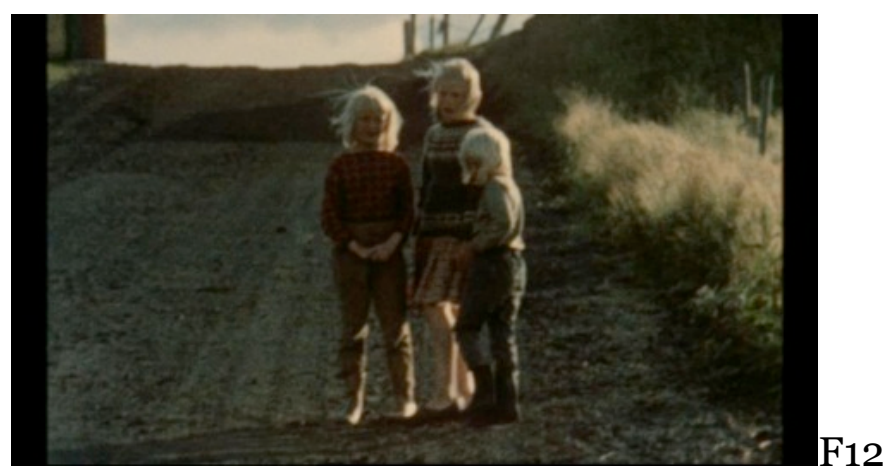

¿Acaso el simple hecho de dejar correr unos pocos segundos la filmación, dejar que se enlacen los fotogramas, aun sin la interferencia de otra imagen, es suficiente para que esa felicidad asociada a la infancia se desvanezca? ¿Es suficiente para que las paredes de la vitrina se hagan añicos? Una vez más tenemos que saltar a través del tejido textual para perfilar esta idea.

Reflexionando sobre la juventud japonesa, tras el déjà vu de Narita, Krasna llega a afirmar: La juventud que se reúne todos los fines de semana en Shinjuku sabe que no es una catapulta hacia la vida real sino que es una vida que hay que consumir enseguida, como las grosellas. Es un secreto muy simple, los viejos intentan esconderlo y no todos los jóvenes lo saben. Es precisamente en Tokio donde encuentra el mejor ejemplo para reflejar ese otro planeta que supone la juventud. Son los jóvenes pertenecientes a la tribu urbana de los takenoko. Los ve bailar todos los domingos en el parque Yoyogi, bebés marcianos que viven en un tiempo paralelo, una pared de acuario invisible que les separa de la multitud que atraen... hasta que llegan 
a los veinte años de edad. Justo antes de reencontrarnos con los niños islandeses, su mirada se centra en la ceremonia del "15 de Enero", una celebración obligada en la vida de toda joven japonesa en su vigésimo aniversario. Se define como una ceremonia de graduación donde se establece la frontera que debe separar la infancia y juventud de la mujer y el inicio de su edad adulta, y en la que reciben como regalo de los ayuntamientos toda una batería de guías y recomendaciones sobre cómo ser una buena ciudadana, una buena esposa, una buena madre. Los fines de semana en Shinjuku y el planeta takenoko se alejarán de ellas a medida que, como los niños islandeses, recorran su propio camino hacia el incierto horizonte que les aguarda. Krasna las contempla ataviadas con sus tradicionales kimonos, radiantes, mientras se pregunta a sí mismo en el frío invierno tokiota: ¿Cuánto tiempo tardarán en olvidar el secreto?

Volvemos entonces a Islandia para comprobar que aquello que debía omitirse en el plano inicial de Sans Soleil, para que esa imagen propia de la felicidad no perdiera su nitidez, era precisamente el horizonte al fondo como metáfora del futuro, del porvenir que arrastrará a los tres niños por ese otro camino simbólico, relacionado con el aprendizaje, con el acceso al conocimiento, y al dolor y angustia que conlleva. Su recorrido les enseñará que los pandas mueren, que las revoluciones no sirven sino para aprender con la derrota, y, sobre todo, que el horror en cualquier momento puede devolverte la mirada. La felicidad asociada a la inocencia infantil se desvanecerá tan rápido como la imagen pueda ser puesta en relación, ahora sí, fuera de la protección de la vitrina, con otras imágenes en la espiral de la memoria. Una vez más, tan sólo bastaría con esperar el trabajo del Tiempo. Entonces, como ya advirtieran las palabras de Krasna en la obertura del filme, vemos el siniestro reverso que ocultaba la imagen-fetiche de Islandia: una imagen formalizada a conveniencia para ser conservada como un necesario bálsamo para la conciencia, para intentar construir desde ella las bases de algo nuevo, de una nueva historia, de una nueva memoria, pero que a pesar de todo termina por revelarse inútil, precisamente, a causa de la condena que supone su particular ontología cinema-foto-gráfica, la cual, la 
conecta físicamente con una realidad pasada, con un aquí y un ahora ya inaccesible. ¿Realmente se puede vencer al Tiempo con una imagen-huella que con su promesa de inmortalidad, de resurrección de lo ausente, no hace sino remarcarnos el paso implacable de ese mismo Tiempo?

En este sentido, ya en uno de sus primeros trabajos, Dimanche à Pekin (1956), Marker aseguraba: No hay nada más bello que París, salvo el recuerdo de París. Y no hay nada más bello que Pekín, salvo el recuerdo de Pekín. Y yo, en París, me acuerdo de Pekín...y cuento mis tesoros. En Sans Soleil, este sentimiento de exaltación nostálgica de lo recordado por encima de lo presente se torna en una melancolía dolorosa, abrumadora que Marker reconoce en su visita al museo Jozankei en Hokkaido, cuando sus salas repletas de animales disecados representando escenas sexuales le hacen lamentar el paraíso perdido, el mítico edén donde el sufrimiento de los hombres-bestias no tenía lugar. Más que la pérdida, la abrumadora certeza de saberlo perdido definitivamente y la herida traumática que ello supone (F13). Una herida condenada a nunca cerrarse puesto que es la inflingida por el propio Tiempo que nos arrastra, y así es subrayado, recordando unas palabras atribuidas a Samura Koichi: ¿Quién ha dicho que el tiempo cura todas las heridas? Sería mejor decir que el tiempo lo cura todo, salvo las heridas. Con el tiempo, la llaga de la separación pierde sus límites reales. Con el tiempo, el cuerpo deseado pronto desaparecerá y si el cuerpo que desea ha dejado de existir para el otro lo que queda es una herida sin cuerpo.

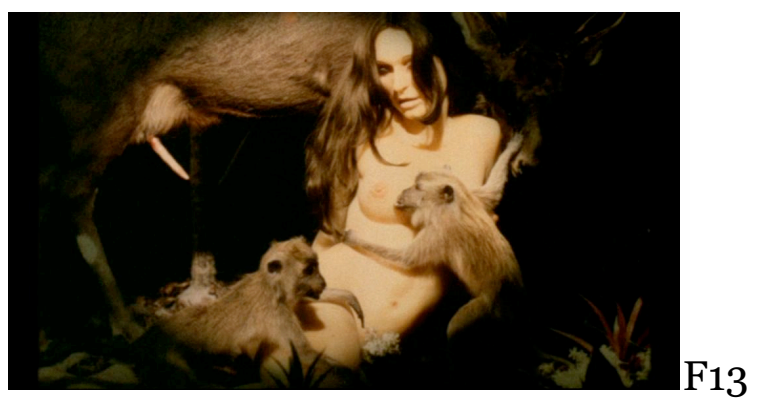

Es esta la terrible evidencia que recorre decisivamente el filme tras quedar inscrita esa llaga de la separación, referida por Koichi, en cada una de las imágenes relacionadas con la memoria humana que lo componen. Imágenes 
fantasmagóricas, arremolinadas en la espiral, en espera de encauzar un sentido a través de un cuento imposible que jamás llegará a ser narrado: Las leyendas nacen de la necesidad de descifrar lo indescifrable. La memorias deben conformarse con su delirio, con su deriva.

\section{Conclusiones: bienvenidos a la Zona}

En Sans Soleil, la futurista Tokio muestra a Krasna en sus salas recreativas los videojuegos que pronto conquistarían el mundo, sobre todo uno en especial, el archiconocido Pac-Man, donde el viajero reconoce la perfecta metáfora gráfica del destino del ser humano: representa las relaciones de fuerza del individuo y el entorno y nos anuncia con soberbia que a pesar del honor de realizar muchos asaltos victoriosos al final siempre acaba mal. Marker, cronista de la derrota del siglo XX, en su ensayo titulado $A$ free replay: notes on Vértigo ${ }^{6}$-a vueltas una vez más con la dictadura del tiempo y la memoria- escribe que los videojuegos dicen más de nuestro inconsciente que las obras completas de Lacan: ni dinero ni gloria, sólo una nueva partida 7 (Marker, 1994, sp). ¿Acaso no era esto lo único que anhelaba Scottie, simplemente una nueva partida, otra oportunidad? Para hacerlo posible: el sintetizador de imágenes, la siguiente fase del plan de asistencia de las máquinas a la humanidad.

Siguiendo con nuestro particular itinerario a través de Sans Soleil, es momento de recapitular nuestras conclusiones y aproximarnos definitivamente a la Zona, y, con ella, a la promesa de una nueva era, la de la todopoderosa imagen digital, la cual pasará a ocupar un lugar eminente en la constante interrogación sobre la imagen, el tiempo y la memoria que, ya señalábamos en la presentación del artículo, orientaría las grandes preocupaciones de la obra de Chris Marker hasta la fecha de su muerte.

\footnotetext{
${ }^{6}$ Texto publicado originalmente en Positif, $\mathrm{n}^{0}$ 400, julio 1994.

7 Traducción propia. Texto original: "What do video games, which tell us more about our unconscious than the works of Lacan, offer us? Neither money nor glory, but a new game". En http://www.chrismarker.org/a-free-replay-notes-on-vertigo/
} 
Según Santos Zunzunegui, mientras que Godard habla de la "tumba para el ojo", Marker afronta el post-cine con optimismo considerando que "el espacio multimedia ante el que se encuentra tiene mucho de tierra ignota en la que es necesario abrirse paso empujando cada vez un poco más lejos sus fronteras” (Zunzunegui, 2006, 168-169). Efectivamente, Marker mira esperanzado hacia las posibilidades que le brindan los nuevos equipos y programas informáticos de procesamiento y almacenamiento de imágenes y datos, e incorpora elementos como el Apple PowerMacintosh 8100 y el software de creación multimedia HyperStudio de Roger Wagner a sus habituales herramientas de trabajo, lo que se traduce en la producción markeriana desde comienzos de los años 80, cada vez más familiarizada con conceptos como los entornos virtuales, las bases de datos, la interactividad o internet hasta el culmen que supone el CD-ROM Immemory.

Para Marker, las nuevas tecnologías mediáticas electrónicas y los sistemas de procesamiento de la imagen que utiliza para componer sus trabajos son herramientas que había estado anticipando durante gran parte de su vida creativa, y que ahora le llevan a considerar el cine como algo con lo que había tenido que conformarse hasta entonces (Lupton, 2006, 186).

Sería necesario esperar a Level Five (Marker 1996), el que a la postre se ha convertido en el prematuro último largometraje de su carrera, para que el ordenador entendido tanto máquina física como entorno virtual donde el sujeto se relaciona con otros sujetos se convierta en el verdadero centro del discurso markeriano sobre la memoria, y a la citada Immemory para que esa concepción en espiral del tiempo y la memoria que hemos estudiado en Sans Soleil, termine de encontrar su mejor expresión en la estructura "rizomática, arborescente, del CD-ROM y de otras formas de organización textual que permite un dispositivo hipertextual” (Ortega \& Weinrichter, 2006, 43).

El hipertexto, concepto acuñado por Theodore Nelson en los años 6o, se caracteriza por ser un texto que desarrolla una escritura no secuencial, un texto que se ramifica y presenta opciones al lector. Tras sus experimentos relacionados con la multiplicidad de monitores en Zapping Zone (1990- 
1997), y con el montaje aleatorio determinado por un programa informático en Silent Movie (1995), Marker terminará encontrando en el hipertexto informático una vía para trascender la linealidad a la que se veía obligatoriamente limitado por el cine, y poder así plasmar una escritura más relacionada con la estructura de nuestro pensamiento, de nuestra propia memoria.

Las características del cd-rom le convierten en un vehículo ideal para la proyección virtual que hace Marker de su memoria, pues le permiten asociar texto e imagen en nuevas constelaciones hipermediáticas, flexibles e infinitamente abiertas que trascienden los modelos existentes tanto para los libros como para las películas (Lupton, 2006, 212).

En Immemory Marker compone a partir de trozos, de fragmentos, una especie de autobiografía, de retrato personal en el que los recuerdos se entrelazan formando una red en la que el espectador-visitante puede desplazarse, detenerse, observar a voluntad. Todo ello traza el retrato de Marker. Su memoria. Su ser. La expresión hipertextual de Immemory sería, de acuerdo con Zunzunegui la continuación lógica de una escritura en la que las viejas nociones de espacio y movimiento de la imagen cinematográfica se ven sustituidas de una manera cada vez más certera por las nociones de topología y tiempo que Gilles Deleuze identificaba como propias de la imagen contemporánea:

La primera de estas nociones nos lleva a la de mapa, a la cartografía, porque en el viaje a la memoria propuesto por Marker una imagen ya no es como en el relato cinematográfico un punto de transición que presupone la anterior e implica la siguiente sino un auténtico depósito virtual que puede sufrir diferentes actualizaciones según el recorrido en el que se inserte (Zunzunegui, 2006, 166).

El espacio como una cartografía de la memoria en la que las imágenes se entrecruzan, se desvían y se enredan, conjugándose entre si para formar estructuras significantes en permanente actualización. El tiempo no como el continuo curso cronológico de los acontecimientos sino entendido como distintas "capas del pasado" (Deleuze, 1996, 163), todas coexistentes, que se 
reestructuran sin cesar. Sans Soleil, advertíamos, es tan solo el primer paso por esa tierra ignota ciberespacial, referida por Zunzunegui, el punto de arranque de los nuevos caminos que se abrirían ante el explorador Chris Marker, quien, consciente del continuo proceso de sustitución de unas imágenes por otras, propio del ser humano, acepta como natural esa tendencia hacia lo digital que comenzaba a hacerse patente a principios de los años ochenta y que se demostraría inevitable con el paso del tiempo:

La pedagogía crítica (de Marker) se reconoce cada vez más claramente como un trabajo de duelo, el de la imagen-realidad, a la que hay que sustituir con otra imagen, una imagen que se confiesa imagen, pero que no por ello deja de ocupar su lugar en la conciencia. Podemos ver Sans Soleil como una suerte de antepenúltima etapa del duelo, como el canto de cisne de la imagen-realidad, (...) esperando la fase siguiente del plan de asistencia de las máquinas a la especie humana anunciada en Sans Soleil (Kohn, 2006, 111).

Como advierte Olivier Kohn, ese proceso de sustitución de la imagenrealidad por la imagen informática que polarizaría buena parte de la producción markeriana en las últimas tres décadas encuentra su origen en Sans Soleil, donde la imagen-huella de unos niños islandeses terminaba, recordemos, por revelarse ineficaz, pero también donde se identifica la todavía incierta esperanza de salvación gracias al universo virtual, bautizado como la Zona en directo homenaje a Tarkovski (Stalker, 1979), hacia el que parece dirigirse el hondo proceso de duelo de nuestro viajero. Ahora bien, para poder adentrarnos en esa misteriosa tierra es necesaria la mediación, siguiendo con la referencia tarkovskiana, de un particular stalker, de alguien que posibilite el rito iniciático, el acceso.

Para cumplir esa función, todavía desconcertado por su reencuentro con Narita, Krasna nos habla de un supuesto amigo creador de videojuegos ${ }^{8}$. Mi colega, Hayao Yamaneko, ha encontrado una solución: si las imágenes del presente no cambian, hay que cambiar las pasadas. Me mostró las luchas de los sesenta retocadas por su sintetizador. Imágenes menos mentirosas,

8 Todo parece indicar que nos encontramos ante otro de los seudónimos markerianos. Yamaneko se traduce del japonés como "amante de los gatos".

237 
me dice con la convicción de un fanático, que las que ves por televisión. Al menos muestran lo que son, imágenes, y no la forma transportable y compacta de una realidad ya inaccesible. Así es presentada oficialmente en Sans Soleil la maquina de Yamaneko, exactamente, con una mano humana accionando el interruptor de un artefacto electrónico para que las imágenes de las revoluciones sesentayochistas desfilen de nuevo por la pantalla tras romper definitivamente sus vínculos con la realidad y con ellos su condena ontológica.

Krasna dice envidiar a Hayao y su Zona: Observo su máquina y pienso en un mundo en el que cada memoria pueda crear su propia leyenda. Su lenguaje, argumenta, le llega pues se dirige a esa pequeña parte de nosotros que se empeña a dibujar perfiles en las paredes de las prisiones. Bellas palabras para una metáfora que no hace sino incidir en lo que venimos defendiendo en cuanto a esa necesidad de reescribir la memoria que planea a través del filme markeriano. Gracias a la mediación de la máquina, las imágenes fílmicas de Sandor Krasna, sus recuerdos en definitiva, pueden por fin adentrarse en ese nuevo universo ya liberadas de la espiral del tiempo y la memoria, atrapadas $y$ decoradas como insectos a los que contemplar desde el exterior del tiempo, la única eternidad que nos queda. Lejos de toda coordenada espaciotemporal. Lejos de cualquier diferenciación entre lo que es, lo que no es, lo que pudo ser o lo que será. Metamorfoseadas en otra cosa, en pura imagen que sustituye la cruel huella física de lo real por la fría materia electrónica: la única, según Yamaneko, capaz de tratar el sentimiento, la memoria y la imaginación.
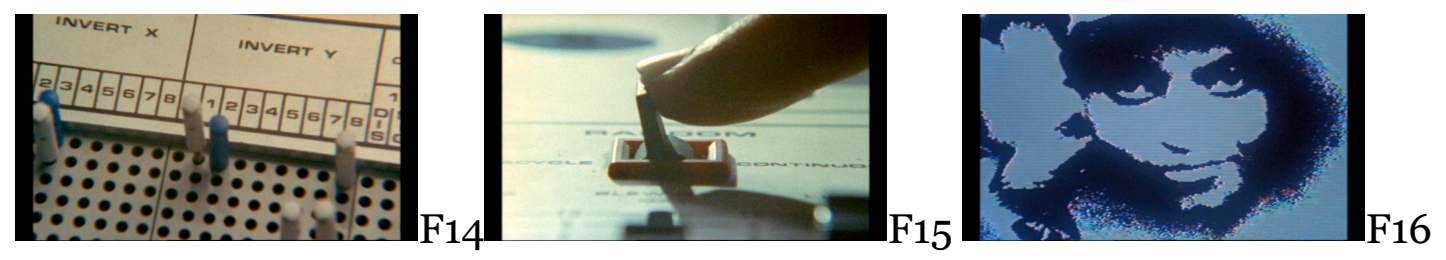

Habría que aguardar con incertidumbre esa posible carta a la que se refiere la narradora en su comentario final para confirmar el desenlace, siempre que Krasna consiga regresar de su viaje por la Zona. De momento, en Sans Soleil tenemos que conformarnos con el último escrito recibido, donde cuenta que 
por fin puede fijar la mirada de la mujer del mercado de Praia que sólo duraba el tiempo de un fotograma (F16). A ella está dedicada la última imagen del film, cuando gracias a los interruptores de la máquina, unos dedos humanos (F14-F15) consiguen congelar en la Zona ese rostro donde se condensa todo el fracaso de la revolución, pero también la esperanza que brilla entre las ruinas.

\section{Referencias bibliográficas}

Barthes, Roland (1990). La cámara lúcida. Barcelona: Paidós.

Deleuze, Gilles (1996). La Imagen-tiempo. Estudios sobre cine 2. Barcelona: Paidós.

Dubois, Philippe (1996). El acto fotográfico. De la representación a la recepción. Barcelona: Paidós.

Fontcuberta, Joan (1997). El beso de Judas, fotografía y verdad. Barcelona: Gustavo Gili.

Gauthier, Guy (2003). “Chris Marker, explorador del espacio y del tiempo”. Ensayo incluido en la programación de la exposición: Chris Marker. Bilbao: Museo de BBAA.

Kohn, Olivier (2006). Tan lejos, tan cerca. En Mystère Marker, pasajes en la obra de Chris Marker (Ortega, $\mathrm{M}^{\mathrm{a}}$ L. y Weinrichter, A. eds.), Madrid: T\&B Editores, pp. 107-112.

Ledo Andión, Margarita (2005). Cine de fotógrafos. Barcelona: Gustavo Gili.

Losilla, Carlos (2006). La espiral es un rostro de mujer. En Mystère Marker, pasajes en la obra de Chris Marker (Ortega, Ma L. y Weinrichter, A. eds.), Madrid: T\&B Editores, pp. 139-148.

Lupton, Catherine (2006). Recuerdos del futuro. En Mystère Marker, pasajes en la obra de Chris Marker (Ortega, $\mathrm{M}^{\mathrm{a}}$ L. y Weinrichter, A. eds.), Madrid: T\&B Editores, pp. 185-220.

Marker, Chris (1994). A free replay, notes on Vertigo. En: http://www.chrismarker.org/a-free-replay-notes-on-vertigo/

Ortega, Ma L. y Weinrichter, A (ed.) (2006). Mystère Marker, pasajes en la obra de Chris Marker. Madrid: T\&B Editores.

Quintana, Ángel (2011). Después del cine. Imagen y realidad en la era digital. Barcelona: Acantilado.

Weinrichter, Antonio (2006). Montage Marker. En Mystère Marker, pasajes en la obra de Chris Marker (Ortega, $\mathrm{M}^{\mathrm{a}}$ L. y Weinrichter, A. eds.), Madrid: T\&B Editores, pp. 171-184. 
Zunzunegui, Santos (2006). El coleccionista y el explorador, a propósito de Immemory. En Mystère Marker, pasajes en la obra de Chris Marker (Ortega, Ma L. y Weinrichter, A. eds.), Madrid: T\&B Editores, pp. 165170. 